\title{
CLIENTS' PREFERENCES AND DEVELOPMENT OF ORGANIC FOOD DISTRIBUTION CHANNELS ${ }^{1}$
}

\author{
Elżbieta Olech, Maciej Kuboń \\ Institute of Agricultural Engineering and Informatics, University of Agriculture in Krakow \\ *Contact details: elaolech@gmail.com
}

\begin{tabular}{|c|c|}
\hline ARTICLE INFO & ABSTRACT \\
\hline $\begin{array}{l}\text { Article history: } \\
\text { Received: August } 2015 \\
\text { Received in the revised form: } \\
\text { September } 2015 \\
\text { Accepted: October } 2015\end{array}$ & $\begin{array}{l}\text { The objective of the paper was to know preferences of consumers } \\
\text { from Małopolskie Voivodeship as a fundamental factor of growth and } \\
\text { functioning of distribution channels of organic products. A fast devel- } \\
\text { opment of the organic products market as well as growing require- } \\
\text { ments of the society with regard to the quality of sale and form are }\end{array}$ \\
\hline $\begin{array}{l}\text { Key words: } \\
\text { preferences, } \\
\text { client, } \\
\text { channel, } \\
\text { distribution, } \\
\text { ecology }\end{array}$ & $\begin{array}{l}\text { of goods and the form in which the product is offered to them. Re- } \\
\text { search and analyses are a precious source of information for agricul- } \\
\text { tural producers on account of production orientation and the form of } \\
\text { sale. It will also facilitate development of existing distribution chan- } \\
\text { nels and formation of new ones. Research results indicate that con- } \\
\text { sumers are interested in the purchase of products in small packaging } \\
\text { or loose. Sums which they spend on organic food do not exceed PLN } \\
400 \text { per a month. }\end{array}$ \\
\hline
\end{tabular}

\section{Introduction}

On account of the growing knowledge on ecology, interest in organic food has been growing among the society in recent years (Siedlecka, 2014). However, the eco-products market in Poland has been developing more slowly than in other EU countries (Wójcik, 2012). The reported growth of interest in organic products and the growing awareness of consumers concerning the food quality do not translate into development of the organic products market in Poland (Komorowska, 2006; Pawlewicz, Gotkiewicz, 2012; Kuboń et al., 2014). Presently, the following organic food distribution channels are the most popular: direct sale, with numerous various forms (starting with shops which are located at farms, fairs, ending with the subscription system for vegetables and fruit and home deliveries), specialist shops, where organic food participation in the assortment is considerably high and is between several and few dozen percent; multi-area stores, where a wide variety of products and other services are available at the same time (Kociszewski, 2014). In order to properly orient further development of organic food distribution channels, determinants, which shape demand for these products, should be recognized. First of all, changes in con-

1 This Research was financed by the Ministry of Science and Higher Education of the Republic of Poland" 
sumers' lifestyles as well as changes in expectations towards production or consumption should be included. It aims at orienting producers to adjust their products and shape their distribution channels to consumers' expectations by the use of information (Niewęglowski et al., 2014). Thanks to such research, significant information may be obtained. It is necessary to know consumers' preferences, behaviour, customs concerning organic food, which will be helpful to modify existing distribution channels and form new ones (Jasiulewicz, 2008).

\section{Methodology and description of responders}

In order to obtain more extensive information concerning sale of organic products and to know consumers' opinion on the functioning of distribution channels and sale structure, extensive survey was carried out in the region of Małopolska. A detailed study of the organic products' market from the point of view of economy and marketing shows that the best possibility is to carry out research and market analysis so that its main element is recognition of the market and at the same time recognition of clients' demands and requirements. Results of such analysis are a great support for producers because they provide necessary knowledge, which enables orientation of production to specific requirements, finding a production niche, selecting a relevant distribution channel and thus to be more competitive among other producers (Żakowska-Biemans, 2006).

The research uses the quality and quantity method, which is carried out in the form of a guided survey. A 100 - person mixed group purposefully selected was a trial. The trial was divided according to such criteria as, sex, age, financial situation, education, place of residence, number of people in a household, number of children in a household. For the purpose of this article two criteria were found to be the most relevant: a place of residence and respondents' education. In majority of questions, the respondents could choose more than one answer. Therefore, in the analysis presented on plots, the sum is usually more than $100 \%$.

From among the surveyed persons $54 \%$ were women and $46 \%$ were men. The most numerous group was within 26-35 years (it was 33\%). Whereas, the least numerous group consisted of people above 45 years of age and was $11 \% .38 \%$, which is the highest number, were people who live in the country. The lowest percentage of people lived in a town with 20 to 50 thousand of citizens. Taking into consideration the education criterion, the most numerous group of respondents consisted of people with secondary education $-52 \%$.

\section{Research results}

The knowledge of the amount of money which consumers plan to spend or they have already spent on organic food is an essential element of planning and development of distribution channels. Figure 1 presents the amount of money, which respondents spend on organic food on account of the assumed criteria. 
Clients' preferences...

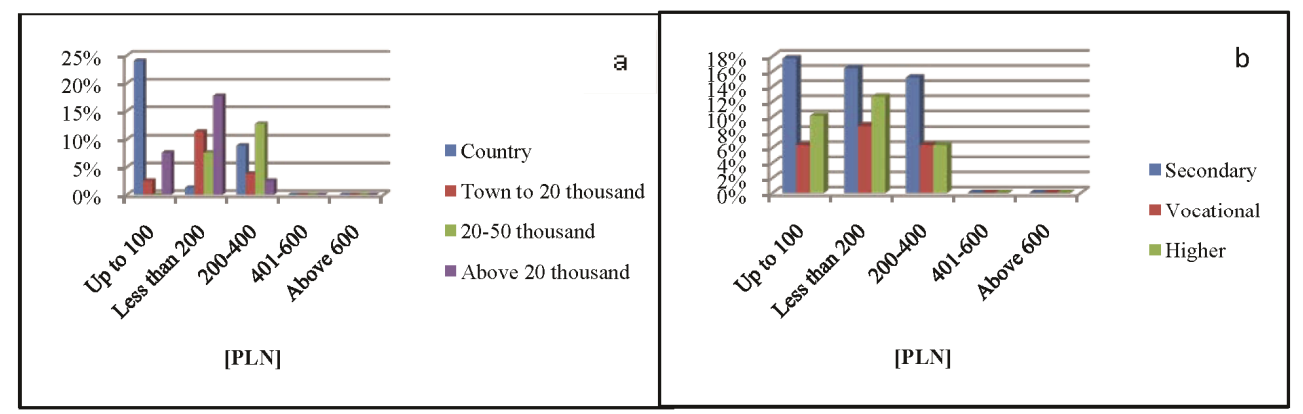

Figure 1. The amount of money in PLN which respondents spend on organic food on account of the place of residence (a) and respondents' education (b)

It was found out that none of the questioned persons spend more than PLN 400 on organic food. As it may be noticed, people with secondary school education spend the most on organic food (PLN 100-200) whereas people with higher and vocational education spend often up to PLN 200. The research has proved that persons which live in rural areas spend even less - up to PLN 100. Probably it follows from the fact, that it is easier for them to purchase some products than to manufacture them since the production cost exceeds the purchase price in shops. Persons living in towns (from 20 to 50 thousand people) spend from PLN 200 to 400 and persons from small towns and big cities (up to 20 thousand and above 50 thousand) allot from PLN 100 to 200 to organic food.

Consumers, notwithstanding the accepted division criteria, provide special shop racks in big stores and organic food stores - which function as separate places in big super-markets as basic places of shopping. However, it should be noted that the purchase directly at a producer and in the Internet has become more popular form of shopping. Figure 2 presents places where the surveyed people purchase organic food.

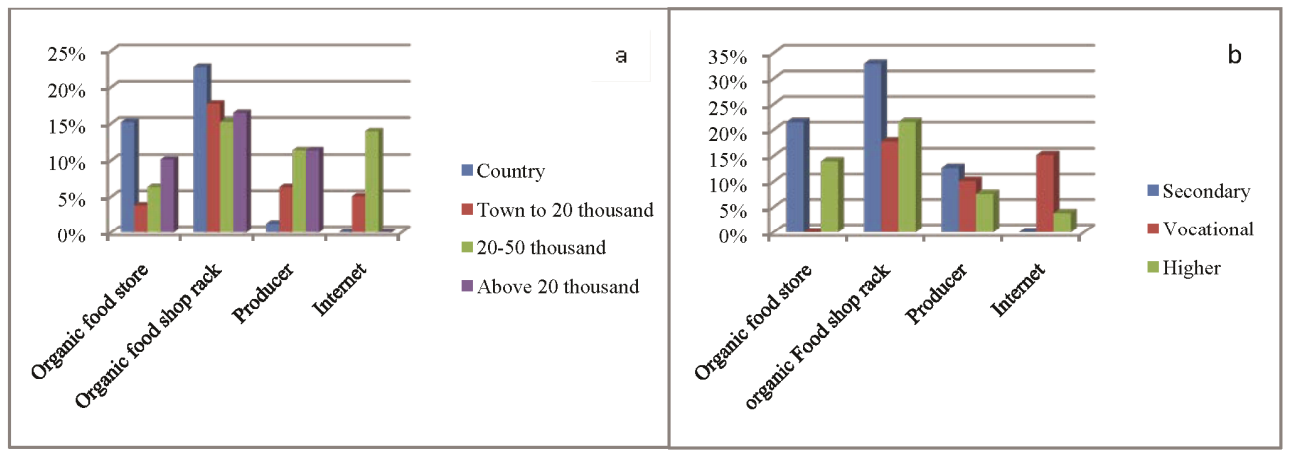

Figure 2. Preferred places where organic food is purchased on account of the place of residence (a) and respondents' education (b) 
Consumers, due to lack of time, appreciate more on-line shopping and the use of the socalled "Package from a Farmer", where products bought for a specific minimum amount are delivered by a producer to a consumer. An often solution is ordering some products at a producer a year ahead, in which case, a farmer orients his production towards specific clients' needs. People living in big city agglomerations prefer this method.

Food, which is available on the market must be secured for buyers, properly packed and unitised for the market needs. Consumers have varied preferences concerning the size of single batches of purchase, which depends on the product and the place of purchase. It often depends on the household size, education as well as the place of residence.

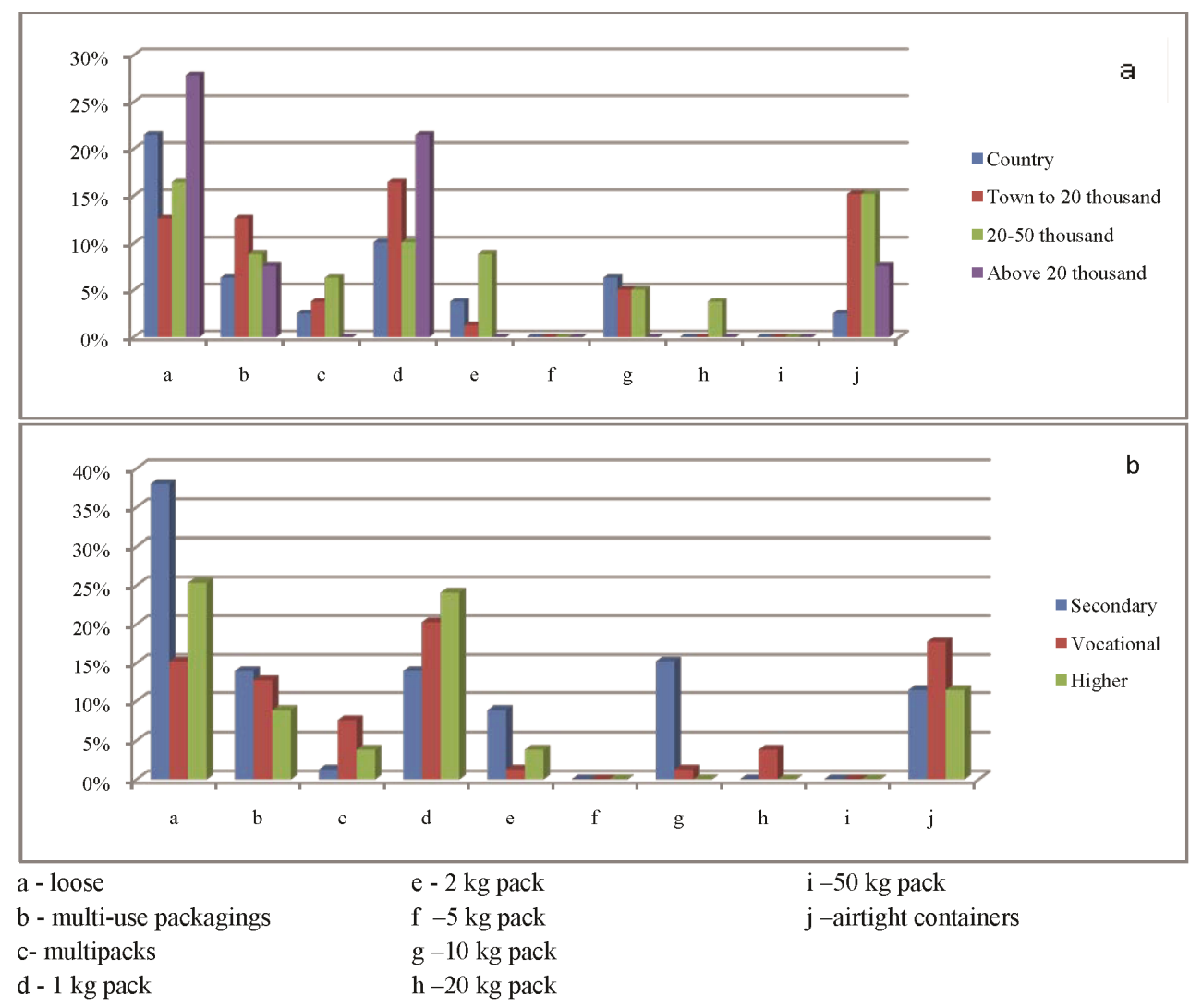

Figure 3. Type of packaging, in which organic food is packed preferred in case of single shopping on account of the place of residence (a) and respondents' education (b)

Analysis of the accepted types of unit packaging in which consumers prefer to buy organic food shows that most often they buy loose products (vegetable, fruit) by the weight and packed in packaging which weigh 1 kilo. It follows from the fact they are handy, give a possibility to buy smaller amount of a product and to reach for new fresh products more often. However, it should be mentioned that products packed in airtight packaging have 
Clients' preferences...

become more popular. The most probably it results from the fact that the society wants to spend less time to prepare meals and thus reaches for semi-ready or ready-made products. Purchase of packed products gives a chance to limit the time spent for preparing meals and limits the frequency of shopping.

A natural form of products prevails in clients' wishes. These are products, for which consumers reach the most often due to their taste and pro-health values and it is related to vegetables and fruit.

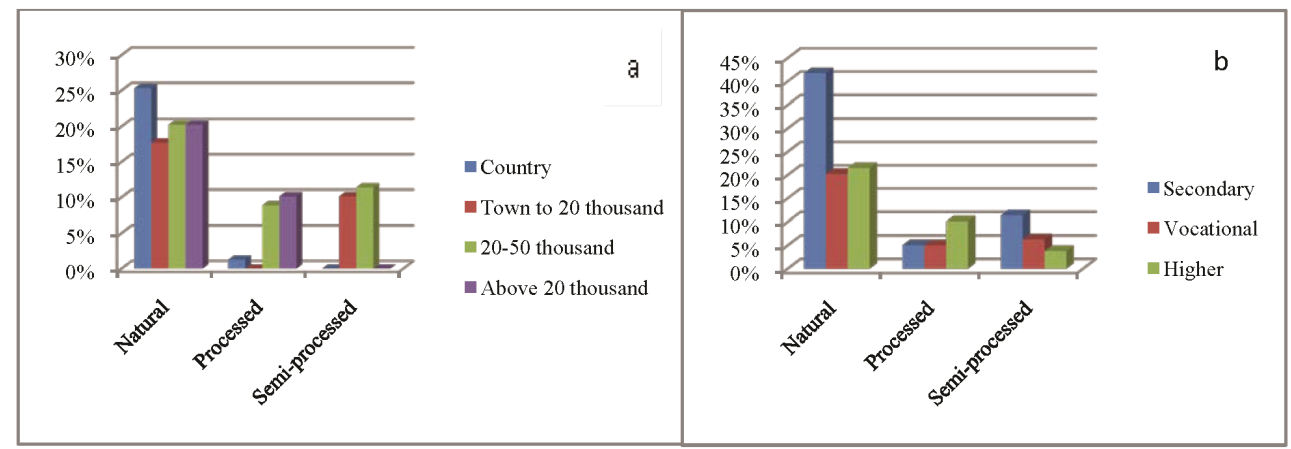

Figure 4. The form of the sold organic food on account of the place of residence (a) and respondents' education (b)

Consumers, regardless the accepted division criteria, more frequently reach for natural products. Persons, who live in bigger cities with a secondary or higher education, are also interested in processed and semi-processed products.

Sources of consumers' knowledge on organic food are a significant factor, which may improve functioning of distribution channels. It is important to know where and which information consumers search for. It is essential in particular for producers, who will have a possibility to use these places as a form of promotion and advertisement of their products - the increase of the amount of information in any media raises the reliability and gives a possibility to increase the sale.

Although the on-line shopping is still at the initial phase of development it may be observed that it is the main place where consumers search for information on organic products. Presently, access to the Internet is great and clients may check any time the information, in which they are interested at this moment. Although, the Internet is the main source of information, clients also use information obtained from press, radio and directly from farmers. It should be mentioned that direct sale has been recently facilitated for a farmer. It results from the act of 9th April 2015, which enables farmers to produce to a small extent without being burdened by tax. Incomes from sale of products, which do not exceed PLN 7 thousand (in a tax year) would guarantee tax release. Moreover, a second possibility provides that incomes from direct sale and pursuant to the act on income tax from natural persons a simplified taxation is carried out at the use of $2 \%$ rate from incomes - a lump sum from registered incomes. Introduction of these changes extends the possibility concerning direct sale, because they could have sold only raw materials from their own farms so far but they could not be processed. 


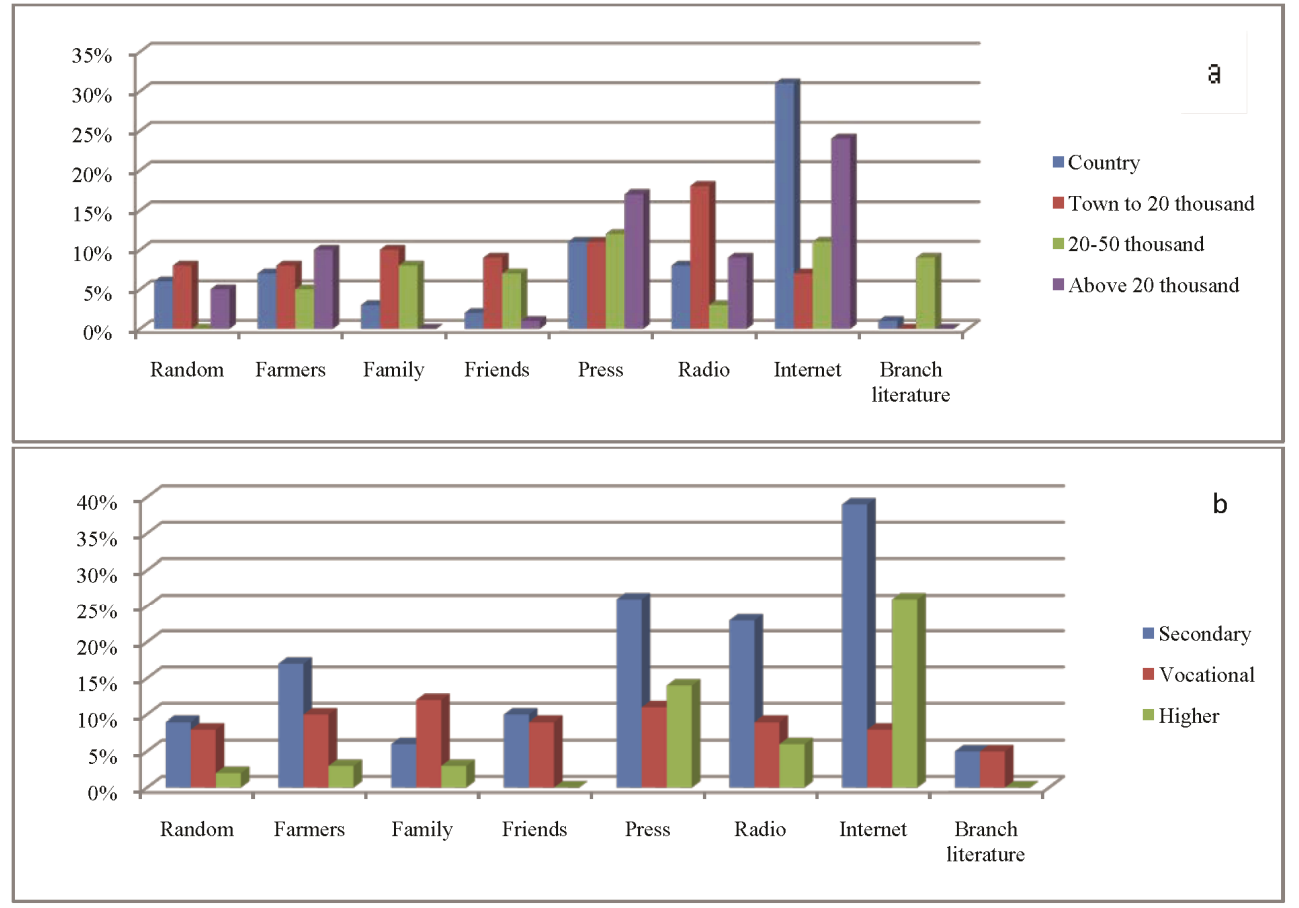

Figure 5. The sources of knowledge on organic food on account of the place of residence (a) and respondents' education (b)

\section{Conclusion}

The organic food market is changing and developing every year. Producers in order to strengthen their position on the market and to increase their incomes more often and in a bigger amount sell organic products which they manufacture searching at the same time for the most accurate and prosperous distribution channels. Such research and analysis provides knowledge on consumers' needs and shapes the direction of changes in distribution channels as well as serves as a prompt for producers what to take into consideration when promoting their products in order to be successful and to strengthen the market position. A growing interest of the society and care for own and family's health induces clients to buy organic products despite high prices. It should be emphasised that clients, more often check information on the product via the Internet before they purchase it. Therefore, producers must pay special attention to a suitable form of promotion of their products and information on them with the use of specialist Internet websites or social networks. It is also important that direct producers of organic products conclude contract with shopping chains in order to extend the access to organic products (shop racks with organic food supplied by them). Due to even faster life pace, interest in the processed and semi-processed food has been growing. It is crucial information for producers, who should gradually intro- 
Clients' preferences...

duce a new wider assortment to the offer so the clients have a wider choice when shopping. One should also pay attention to the frequency of shopping. Clients do shopping more often in smaller quantities to be assured that the products they consume are fresh. Thus, producers should choose packaging to make their product easily available for a consumer.

\section{References}

Jasiulewicz, A. (2008). Wykorzystanie znajomości motywów oraz barier konsumpcji owoców i produktów owocowych w dostosowaniu oferty rynkowej firmy do potrzeb nabywców. Stowarzyszenie Ekonomistów Rolnictwa i Agrobiznesu. Roczniki Naukowe, Tom X, Zeszyt 4, 139-144.

Kociszewski, K. (2014). Bariery i czynniki sprzyjające funkcjonowaniu gospodarstw ekologicznych w świetle wyników ogólnopolskich badań ankietowych. Stowarzyszenie Ekonomistów Rolnictwa i Agrobiznesu. Roczniki Naukowe, Tom XVI, Zeszyt 2, 129-134.

Komorowska, D. (2006). Perspectives of organic farming development in Poland. Problemy rolnictwa światowego, Tom 15, 45.

Kuboń M., Kwaśniewski D., Malaga-Toboła U., Tabor S. (2014). Model solutions of distribution logistics with regard to organic products. Agricultural Engineering, 2(150), 77-90.

Niewęgłowski, M., Jabłonka, R. (2014). Kanały dystrybucji surowców i produktów żywnościowych gospodarstw ekologicznych w regionie siedleckim. Stowarzyszenie Ekonomistów Rolnictwa i Agrobiznesu. Roczniki Naukowe, Tom XVI, Zeszyt 2, 195-199.

Pawlewicz, A,, Gotkiewicz W., 2012. Kanały dystrybucji surowców żywnościowych z gospodarstw ekologicznych w województwie Warmińsko-Mazurskim. Logistyka 4, 1168-1174.

Siedlecka, A., 2014. Wybrane zagadnienia marketingu żywności ekologicznej w gospodarstwach rolnych województwa lubelskiego. J. Agribus. Rural Dev. 3(33), 229-240.

Wójcik, G. (2012). Kreowanie konkurencyjności produktów rolnych na rynku krajowym i międzynarodowym. Wiadomości Zootechniczne, 2, 29-36.

Żakowska-Biemans, S. (2006). Czynniki wpływajace na wybór żywności ekologicznej w opinii polskich konsumentów. [W:] Bromatologia Chemia Toksykologiczna. Suplement, 231-235.

\section{PREFERENCJE KLIENTÓW A ROZWÓJ KANALÓW DYSTRYBUCJI PRODUKTÓW EKOLOGICZNYCH}

Streszczenie. Celem pracy było poznanie preferencji konsumentów z terenu województwa małopolskiego jako podstawowego czynnika rozwoju i funkcjonowania kanałów dystrybucji produktów ekologicznych. Obserwujemy szybki rozwój rynku produktów ekologicznych, jak też rosnące wymagania społeczeństwa co do jakości i formy sprzedaży. Coraz częściej konsumenci zwracają uwagę na źródło pochodzenia towaru oraz postać $\mathrm{w}$ jaki produkt jest im proponowany. Prowadzenie takich badań i analiz jest cennym źródłem informacji dla producentów rolnych pod kątem ukierunkowania produkcji oraz doboru odpowiednich form sprzedaży. Ułatwi to również rozwój istniejących już kanałów dystrybucji oraz łatwiejsze tworzenie nowych. Wyniki badań wskazują na fakt, że konsumenci zainteresowani są zakupem produktów w małych opakowaniach lub luzem, a kwoty jakie wydają na produkty ekologiczne nie przekraczają 400 PLN w skali miesiąca.

Słowa kluczowe: preferencje, klient, kanał, dystrybucja, ekologia 